\title{
Evaluation of farming system outputs in Lithuania: methodological proposal
}

\author{
Anastasija Novikova ${ }^{1}$, \\ Lucia Rocchi ${ }^{2}$, \\ Gražina Startiené ${ }^{1}$ \\ ${ }^{1}$ School of Economics and Business, \\ Kaunas University of Technology, \\ Gedimino 50, \\ 44239 Kaunas, Lithuania \\ Email: anastasija.novikova@ktu.lt; \\ grazina.startiene@ktu.lt \\ ${ }^{2}$ Department of Agricultural, \\ Food and Environmental Sciences, \\ University of Perugia, \\ Borgo XX Giugno 74, \\ 06121 Perugia, Italy \\ Email:lucia.rocchi@unipg.it
}

\begin{abstract}
Agriculture produces jointly market and non-market outputs, and their supply depends on the nature of production. The role of agriculture as an economic activity and its consequences are essential for the Lithuanian case study, as agricultural land covers more than a half of the Lithuanian land. The market does not consider the positive and negative externalities created in agroecosystems. Therefore, specific techniques such as stated preferences methods are used for evaluation of non-market outputs in agriculture. Works by foreign researchers provide a comprehensive analysis of the aspects of nontradable agricultural aspects, usually focusing on evaluation of the benefit or damage to society from agricultural activity. There is lack of an integrated evaluation of farming system outputs in view of the specifics and intensity of farming. The main aim of this paper is to present construction of the methodology for integration of evaluation of farming system outputs in Lithuania, with the main focus on non-market outputs, as the values of agricultural market outputs are clear and fully revealed in official statistics. The conventional and organic farming has been selected for the Lithuanian case study. For the both farming systems, the research covers crops (including both cereals and industrials crops) and livestock (including dairy and cattle) production. The choice experiment (CE) method was selected as appropriate for evaluation of non-market outputs of different farming systems in Lithuanian agriculture. The nested logit was selected for econometric modelling of the value of non-market agricultural outputs. Applying the constructed and checked methodology, consumers' willingness to pay for agroecosystem public goods of different farming systems will be elicited during the main survey.
\end{abstract}

Keywords: farming system, market outputs, non-market outputs, conventional farming, extensive farming, choice experiments, Lithuania

\section{INTRODUCTION}

Historically, agriculture has been appreciated as the provider of market output, such as food and fibre, which are necessary for economic growth and development. In recent times, agricultural activities have been appreciated not only for the economic aspects, but for social and environmental as well (Lankoski, 2003; Abler, 2004;
Mann, Wustemann, 2007; Boody, 2008, et al.), thanks to the capacity of agriculture to produce both market and non-market outputs jointly. Market outputs are accounted for in the market economy. However, the market does not consider the positive (i.e. visually appealing agricultural landscape, preserved diversity of flora and fauna, etc.) and negative (i.e. water pollution caused by the use of chemical fertilizers, pesticides and 
herbicides, soil erosion, loss of biodiversity, etc.) externalities produced by agriculture. Generally, conventional or intensive farming supports the society mostly with the market goods, and is usually considered as a producer of negative externalities (Zhukova et al., 2017; Wagner et al., 2017), while organic farming is often known as the alternative and having beneficial impacts on the environment compared to the conventional one (Aldanondo-Ochoa, Almansa-Sáez, 2009; Jespersen et al., 2017). However, positive externalities are not accounted for in the market and are not very easy to quantify.

In the absence of market values, the stated preference methods such as choice experiments $(\mathrm{CE})$ and contingent valuation $(\mathrm{CV})$ are the most suitable and universal for evaluation of nonmarket outputs in agriculture (Adamowicz et al., 1998; Bateman et al., 2002; Bennett, Blamey, 2001). Therefore, the CE method has been selected as appropriate for evaluation of non-market outputs of different farming systems in Lithuanian agriculture. The main aim of this paper is to present construction of the methodology for integration of evaluation of farming system outputs in Lithuania, with the main focus on non-market outputs, as the values of agricultural market outputs are clear and fully revealed in official statistics. The paper is structured as follows: the first section presents the Lithuanian agriculture and its outputs in general; the second part describes the farming activities, selected for the Lithuanian case study; the third part shows the general estimation framework and methods selected for evaluation. Conclusions are drawn in the last section of the paper.

\section{MATERIALS AND METHODS}

\section{Case study: Lithuanian agriculture and its outputs}

Lithuania is a rural country. More than $80 \%$ of the area are rural, while $52 \%$ of the surface land feature agricultural land, and arable land covers 47\% (National Land Service under the Ministry of Agriculture of the Republic of Lithuania, 2017). Conventional farming is the widespread type of farming in Lithuania, which has been used for hundreds of years. However, organic farming has been steadily expanding in Lithuania and in 2017 it covered about $7 \%$ of the national agricultural area (Statistics Lithuania, 2018).

Agriculture is one of the important economic activities in Lithuania. In 2017, agriculture, forestry and fishing contributed to around $3.09 \%$ of Lithuania's GDP, $26.42 \%$ came from the industry, and $60.3 \%$ from the service sector (Statistics Lithuania, 2018).

According to the data by the Statistics Lithuania, in 2017, the gross output in agriculture was EUR $2.63 \mathrm{bln}$, that is $15.8 \%$ higher than in 2016 . The value of the agricultural output in 2017 increased by more than $10 \%$ compared with 2016 . The increase was determined by growing prices on almost all agricultural products (LAEI, 2018). A higher yield of rapeseed, berries, fruits and cereals led to the increase in the agricultural output as well. Also, the animal output increased by more than $26 \%$ in 2017 compared to 2016 . Crop production comprises the major share of the agricultural output. In the period 2013-2017, the crop output accounted for about $60-65 \%$ of all agricultural output. In 2017, the agricultural output included $34.9 \%$ cereals, $18.5 \%$ milk, $12.1 \%$ fodder and other crops, $9.3 \%$ industrial crops, $5.8 \%$ pigs, $5.1 \%$ poultry, $4.2 \%$ cattle and other outputs, such as vegetables, potatoes, orchards, berries and eggs accounted for a very small part of the output, i.e. 1-3\% (Statistics Lithuania, 2018). Cereals, dairy, pigs and poultry account for the major share of the agricultural outputs; therefore, these farming activities and their market and non-marker outputs are analysed more deeply.

Cereals/crops. In Lithuania, more than one third of the agricultural output is cereal output. According to the data by Statistics Lithuania, cereal output increased significantly in the period 2012-2017 and accounted for about 75\% of the entire crop area in 2017. In this period, the area of perennial grasslands decreased about 3 times. This tendency had a negative impact on biodiversity, caused the increase in mineral fertiliser use and intensive land use, etc. (LAEI, 2018). The aesthetic quality of agricultural landscapes could carry a very high aesthetic value for people (Junge et al., 2015), in particular, in terms of such colourful and variable landscapes as rapeseed. Industrial crops are usually perceived as possessing this aesthetic value. According to the classification of Economic Accounts 
for Agriculture, the category of industrial crops in Lithuania consists of rapeseed, flax, dry pulses, and sugar beet. The major share of industrial crop output includes rapeseed (about 50\%) and dry pulses (about 45\%). Sugar beets account for about $9 \%$ of the industrial crops output (Statistics Lithuania, 2018). According to the new green direct payment scheme introduced by the CAP, launched in 2015, Lithuania has considerably increased the area of dry pulses. The increase between 2013 and 2015 was $64.7 \%$ at the EU level and up to $253.6 \%$ in Lithuania. Cultivation of nitrogen-fixing crops (such as dry pulses) is one of the options available for implementation of the ecological focus areas (De Cicco, 2016), which are beneficial for the climate and environment (Scottish Government, 2018).

Crop industry behind market outputs (such as buckwheat, winter cereals, oat, winter barley, spring barley, grain maize, triticale, rye, flax, sugar beet, rapeseed, etc.) has also been found to have both positive and negative externalities (Novikova, Startiene, 2018).

Livestock. According to the data by Statistics Lithuania (2018), in the period 2013-2017, the quantities of cattle, dairy cows and pigs were decreasing, while the quantities of poultry and sheep were increasing. The decreasing number of cattle and dairy cows was determined by lower purchasing prices of milk and pigs. In 2017, 1617 thousand tonnes of milk were milked, about $90 \%$ were purchased for processing. In comparison to 2016, milk production decreased by $0.7 \%$, compared to $6.2 \%$ in 2013. The number of farms keeping cows decreased by $41 \%$ in $2013-2017$ (LAEI, 2017). Dairy farming has been found to have produced market outputs such as drinking milk and multiple processed products (cream, sour milk, kefir, yoghurt and other) (Statistics Lithuania, 2018) and some negative externalities, such as: ammonia emissions into the air, contamination with nitrates, greenhouse emissions, nitrogen run off (Novikova, Startiene, 2018).

In 2017, 17 thousand farmers kept 611.9 thousand of pigs, of which 50.3 thousand were breeding sows, and farmers raised 1.2 million of pigs, of which 310 thousand were exported and the remaining 880 thousand were butchered. In the period 2013-2017, the number of pigs decreased by 19\%: in 2014, the African Swine Fever appeared in Lithuania and spread to the centre of Lithuania by 2017 . This caused the decrease in the number of pigs and restrictions related to their keeping. The average number of pigs in Lithuanian farms is one of the smallest in EU - 13 pigs (LAEI, 2018). In terms of poultry production, the major share was hens (laying hens mainly), geese, ducks, turkeys, and others accounted for just $2 \%$. In the period 2013-2015, the number of hens increased by almost 7\%; however, the number of ducks and turkeys decreased, respectively by $59 \%$ and 11\% (Statistics Lithuania, 2018). The pigs and poultry have been found to produce meat and eggs for the market and negative externalities as nitrate run off, nitrogen emissions into the air, phosphorus surplus, which has impact on soil, air and water.

According to the Ministry of Agriculture of the Republic of Lithuania (2014), national agriculture does not have a very negative impact on water, as the concentration of the nitrogen and phosphorus combination does not exceed the requirements for drinking water. However, they have also emphasized that, in the intensive farming areas, a certain impact of diffused contamination has been recorded. It has been found that there is still a need to invest into manure management technologies, as well as to keeping, and distribution of the manure and other actions, which could reduce the contamination of water (European Commission, 2013). At present, regular livestock feed supply technologies (high protein feed) are used in the livestock sector, and livestock is usually kept in closed-type pens using the respective livestock keeping technologies designed for closed-type pen keeping and characterised by NH3 emissions from manure (Ministry of Agriculture of the Republic of Lithuania, 2014), causing a negative effect on the environment. In Lithuania, all farmers perform keeping and growing activities under the animal welfare policy and requirements (State Food and Veterinary Service, 2018), so that the consumers could be provided with a good quality meat product and be sure that the animals are grown in adequate conditions.

\section{Selection of farming activities}

The selection of farming activities for the study was done following the literature analysis of farming 
systems and their outputs and the analysis of Lithuanian agricultural sector, of market output and identification of different positive and negative externalities caused by them. The general framework idea has been developed on the basis of the nested logit tree structure (Hensher et al., 2005) where the farming system is managed in two ways: conventionally and organically, considering two main agricultural activities: crop and livestock production as shown in the Figure.

In order to reveal different outputs under the agro-technological approach, conventional and organic farming have been selected for the analysis. Conventional farming is the most common farming type, while organic farming is the growing form of low-input farming systems in Lithuania, and the alternative to conventional farming. For the both farming systems, the research includes crops (including both cereals and industrials crops) and livestock (including dairy and cattle) production. This choice has been made as the both farming activities are implemented conventionally and organically, account for the largest share of the output (about $70 \%$ of the entire agricultural output) and cover almost the entire UAA/are implemented on the vast territory of Lithuania. Therefore, they doubtlessly generate non-market output, which is perceived by Lithuanian society.

\section{Estimation framework}

The market output and gross value added from agriculture have been already evaluated and the data is fully available in the national data bases, Eurostat, FAO, etc. Market agricultural outputs are analysed on a micro level on the basis of the FADN data, and on a macro level on the basis of data of the economic accounts. For example, works by researchers at the Lithuanian Institute of Agrarian Economics have been dealing with analysis of economic agricultural outputs, overviewing market outputs of the agricultural sector, its individual areas on a macro or micro level, in other words, dealing with economic results, such as output, GVA, NVA only. This kind of analysis is not challenging because of availability of the entire statistical information. However, valuation of non-market agricultural outputs is always under discussion and a lot of attempts are made to evaluate it using specific environmental valuation methods. For example, some researches have focused on the value of the benefit provided by agroecosystems (Arriaza et al., 2008; Bernués et al., 2015; Grammatikopoulou et al., 2012; Jianjun et al., 2018), others on the value of damage to society and environment (Teizzi, 1999; Pretty et al., 2001; Tegtmeier, Duffy, 2004; Tait, Cullen, 2006).

The Choice Experiments (CE) technique is a stated preference method widely applied to estimate non-market goods, by using the hypothetical choice scenarios. CE have been applied to evaluation of ecosystem services in several research works (i.e. Chaikaew et al., 2017; Christie, Rayment, 2012; Doherty et al., 2014; Marre et al., 2015; Olschewski et al., 2012; Enriquez-Acevedoa, 2018; Rakotonarivo et al., 2017; Soto et al., 2018), whilst the use for non-market output from agricultural is still rare (Novikova et al., 2017; Szabo, 2010; Arriaza et al., 2008).

CE are based on the Lancaster's Theory of Value (Lancaster, 1966) and the Random Utility

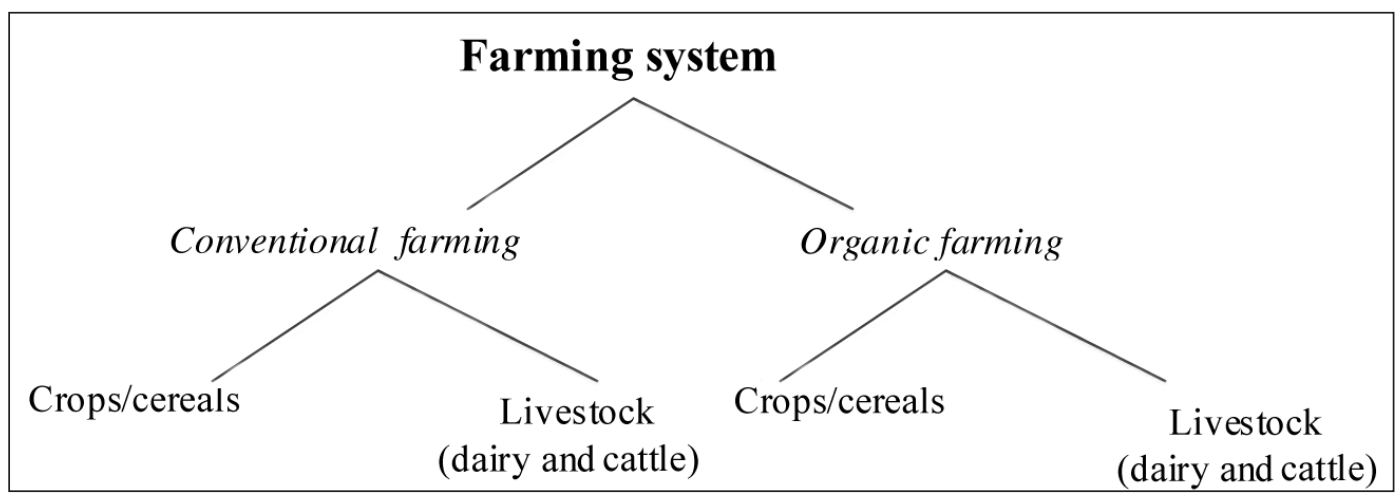

Figure. Farming systems for the Lithuanian case study 
Theory (RUT) (Thurstone, 1927). In CE, respondents are asked repeatedly to choose between different alternatives, composed of several attributes, each one expressed by a certain level. The presence of a monetary attribute (price, tax or cost) allows calculating the marginal utility for money (Marginal Willingness to Pay - MWTP) (Aravena et al., 2014). The basic assumption is that people seek to maximize utility in each choice situation according to their own preferences (McFadden, 1974). The identification of proper attributes and of their space is very important, because levels and range must be relevant to and meaningful for the issues analysed.

Some authors criticize choice experiments and monetary valuation of natural resources (Neuteleers, Engelen, 2014) for the presence of hypothetical bias, especially in the case of precise WTP evaluation (Chaikaew et al., 2017). However, the hypothetical bias does not make the CE method irrelevant (Allen, Moore, 2016), and the use of monetary evaluation can help decision makers in particular in the case of uncertainty (Kubiszewski et al., 2017).

Allen and Moore (2016) used CE to demonstrate the importance of non-market valuation in a complex scenario for modelling a priori preference for program design and the potential benefit. Novikova et al. (2017) also used CE to understand the preferences of Lithuanian citizens regarding ecosystem services provided by agriculture, in relation to the EU Common Agricultural Policy. Williams and Rolfe (2017) involved CE for the analysis of Australian residents of willingness to support policies aimed at emission reduction, which could be used for correction of the current policy. Jianjun et al. (2018) used CE elaborations to design efficient policies concerning cultivated land protection in China. In authors' opinion, quantifying the benefit of cultivated land protection for residents is very useful for policy-makers. In conclusion, considerable efforts are made to evaluate the non-market output in agriculture using CE; however, there is lack of research on evaluation in the context of different farming systems and their external effects.

\section{Econometric specification}

According to the Random Utility Model (McFadden, 1974), the utility of each element $(k)$ con- sists of an observed component denoted by $V$ and a random component:

$$
U_{k}=U_{k}\left(V_{k}, \varepsilon_{k}\right)
$$

The observed utility $\left(V_{k}\right)$ is a function of the observed attributes $(x)$ of the choice as faced by the individual $(t)$, the observed socioeconomic attributes of the individual $(s)$ and a vector of parameters $(\beta)$ :

$$
V_{k}=V_{k}(x, s, \beta) .
$$

When an individual $\mathrm{t}$ faces a choice set $C_{k}$, consisting of the choice $J_{k}$, the probability of alternative $i$ is equal to the probability that the utility of alternative $i\left(U_{i k}\right)$ is greater than the utilities of all other alternatives in $C_{k}$ :

$$
P_{k}(i)=\operatorname{Pr}\left(V_{i k}+\varepsilon_{i k} \geq V_{j k}+\varepsilon_{j k} \forall j \in C_{j}, j \neq i\right) .
$$

Assuming that the random components are the extreme value distributed, independently across choice and individuals, the probability that the choice $i$ is made can be assessed using a logistic distribution (McFadden, 1974), such as:

$$
P_{k}=\frac{e^{V_{i k}}}{\sum_{j \in j k} e^{V_{i k}}} .
$$

Equation 3, known as the Multinominal Logit model (MNL), can be estimated by Maximum Likelihood techniques, and it is easy and useful for modelling choice behaviour. Although it is a useful reference model, MNL is limited by several assumptions (Vivithkeyoonvong, Jourdain, 2016). One of the major weaknesses of MNL specification emerges from the property of 'Independence of Irrelevant Alternatives' (llA). This property restricts the ratio of the choice probabilities for any pair of alternatives to be independent of the existence and characteristics of other alternatives in the choice set. Therefore, the introduction of a new mode or improvements to any existing mode will reduce the probability of existing modes in proportion to their probabilities before the change. IIA implies an equal competition between all pairs of alternatives, which is an inappropriate assumption in many real-life situations and results from the assumption of the independence of error terms in 
the utility of alternatives, which is used to derive the model. However, different models use different assumptions concerning the structure of the error distributions of alternative utilities. Among them, one of the most popular is the Nested Logit (NL) model (Williams, 1977; McFadden, 1978).

One of the most attractive characteristics of NL models is their ability to accommodate differential degrees of interdependence between subsets of alternatives in a choice set (Hensher, Greene, 2002). Moreover, they are relatively easy to estimate and computationally straightforward. Researchers prefer NL over MNL when there is the possibility that standard deviations (or variances) of the random error components in the utility expressions are different across a group of alternatives within the choice set, which is exactly the situation occurring in this research. In certain cases, they grouped alternatives into Tsubsets (called nests), each one consisting of $t(n)$ alternatives. More levels of nesting can be introduced, by grouping again the alternatives with such a nest in sub-nests. Alternatives in a common nest exhibit a higher degree of similarity and competitiveness than alternatives in different nests. This level of competitiveness, represented by cross-elasticities between pairs of alternatives, is identical for all pairs of alternatives in the nest.

In the NL model the observed utility associated with the $k$ th alternative is defined by four parameters associated with the explanatory variables $\beta$, an alternative-specific constant, $\alpha k$, a scale parameter, $\theta$, and the explanatory variables, $x$ (Hensher, Greene, 2002). Therefore, upon adding the random component $\left(\varepsilon_{t k}\right)$, the utility of alternative $k$ for individual $t$ is

$$
\begin{aligned}
& U_{t k}=g_{k}\left(\alpha_{k}, \beta^{\prime} x_{t k}, \varepsilon_{t k}\right)=g_{k}\left(V_{t k}, \varepsilon_{t k}\right)=\alpha_{t k}+\beta^{\prime} x_{t k}+\varepsilon_{t k}(5) \\
& \operatorname{Var}\left[\varepsilon_{t k}\right]=9^{2}=k / \theta^{2}
\end{aligned}
$$

The scale parameter $(\theta)$ is proportional to inverse of the standard deviation $(\sigma)$ of the random component in the utility expression, and is the critical input into the setup of the NL model (Hensher, Greene, 2002).

The aim of this research is to assess the nonmarket output of conventional and organic farming systems (through residents' WTP analysis), using the choice experiments approach and ap- plying the nested logit specification. In this context, the probability of choice among conventional farming alternatives is given by

$$
P(i \mid C)=\frac{e^{V_{i}}}{e^{V_{\text {crop } 1}+V_{\text {livel }}}} \times 100
$$

where $i=$ crop 1 , crop2.

Then it is possible to calculate $I$, the inclusive value, which is the expected utility from the given branch choice:

$$
I_{C}=\ln \left(e^{V_{c r o p 1}}+e^{V_{\text {live } 1}}\right) .
$$

At the same time for the organic farming

$$
\begin{gathered}
P(i \mid O)=\frac{e^{V_{i}}}{e^{V_{\text {crop } 2}+V 2}}, \\
I_{O}=\ln \left(e^{\left.V_{\text {crop } 2}+e^{V_{\text {live } 2}}\right) .}\right.
\end{gathered}
$$

Then, the model of the choice between farming systems, on the ground of the ecosystem services produced, will be

$$
\begin{aligned}
& P(C)=\frac{e^{\mu\left(\beta_{C}^{\prime}+I_{C}\right)}}{e^{\mu\left(\beta^{\prime}{ }^{+} I_{C}\right)}+e^{\mu I_{O}}}=\frac{e^{\beta_{C}+\mu I_{C}}}{e^{\beta_{C}+\mu I_{C}}+e^{\mu I_{O}}}, \\
& P(O)=\frac{e^{\mu I_{F_{i}}}}{e^{\mu\left(\beta^{\prime}{ }^{+} I_{C}\right)}+e^{\mu I_{O}}}=\frac{e^{\mu I_{F}}}{e^{\beta_{C}+\mu I_{C}}+e^{\mu I_{O}}},
\end{aligned}
$$

where $I_{C}$ and $I_{O}$ are attributes of the nest conventional farming and organic farming, respectively.

$\beta_{C}=\mu \beta_{M}$ and $\mu$ are unknown parameters to be estimated:

$$
0<\mu \leq 1 \text {. }
$$

\section{RESULTS AND FUTURE DEVELOPMENT}

One of the main issues in application of CE in valuation of non-market agricultural outputs is the selection of attributes for the survey. It is a crucial point of all CE (Arriaza et al., 2008). Madureira et al. (2013) state that selection of the attributes for $\mathrm{CE}$ could be done according to the farming impact on natural environment, such as: (1) farming types and their externalities generated; (2) land use; (3) expected changes from the changes in supply of externalities. In literature, agricultural non-market outputs 
usually used as attributes of farming system activities are an aspect of the landscape (i.e. scenic views, sense of the place, suitability for recreation) (Jianjun et al., 2018; Arriaza et al., 2008; Hasund et al., 2011; Takatsuka et al., 2006), biodiversity (i.e. variety of species, flora and fauna, endangered species) (Arriaza et al., 2008; Hasund et al., 2011; Goibov et al., 2012), water quality and availability issues (Baskaran, 2009ab; Goibov et al., 2012; Takatsuka et al., 2006), soil quality aspects, such as erosion and fertility (Jianjun et al., 2018; Khanal et al., 2017; Arriaza et al., 2008; Takatsuka et al., 2006). Moreover, nonmarket agricultural outputs could be selected for the analysis according to the geographical situation, as different countries may be dealing with different issues from agricultural activities. For example, for the Lithuanian case, the water contamination issue could be relevant (KPP, 2014), while countries in the South Europe have issues with water use for irrigation (Madueira et al., 2013), other countries, for example, those in North Africa and
Central Asia have water issues not only with agricultural activities, but with the human living as well (Houessionon et al., 2018).

The levels of attributes in the CE are usually presented as: (1) increase or decrease in percentage, for example, improvement of water quality by 10, 20 or different \% (Baskaran, 2009ab; Arriaza et al., 2008; Goibov et al., 2012; Borresch et al., 2009; Huber et al., 2011; Szabo, 2010); (2) giving the explanation of the attributes by phrases (Borresch et al., 2008; Hasund et al., 2011; Szabo, 2010; Khanal et al., 2017); (3) the relative sizes, such as the expected changes of microelements in water $\mathrm{mg} / \mathrm{l}$, or number of species per area, e.g. species/ sq.km (Goibov et al., 2012; Borresch et al., 2008). Following the analysis of the literature on application of CE in evaluation of non-market outputs of agriculture and the effects of farming system activities and their peculiarities for the Lithuanian case, four attributes with their different levels, representing different farming types have been selected and presented in the Table.

Table. Selection of the attributes for valuation of non-market outputs

\begin{tabular}{|c|c|c|c|}
\hline $\begin{array}{c}\text { Attributes } \\
\text { (functions } \\
\text { of agriculture) }\end{array}$ & Levels for crop production & $\begin{array}{l}\text { Levels for livestock } \\
\text { production }\end{array}$ & $\begin{array}{c}\text { Types of ecosystem } \\
\text { services }\end{array}$ \\
\hline $\begin{array}{c}\text { Landscape (scenic } \\
\text { views, aesthetic } \\
\text { value) }\end{array}$ & $\begin{array}{l}\text { - No variety/monotonic view } \\
\text { - } 2 \text { different crops at the same } \\
\text { time every } 10 \text { ha } \\
\text { - } 3 \text { different crops at the same } \\
\text { time every } 10 \text { ha } \\
4 \text { different crops at the same } \\
\text { time every } 10 \text { ha }\end{array}$ & $\begin{array}{l}\text { - No variety on pastoral farms } \\
\text { - } 10 \% \text { more in scenic views like } \\
\text { trees, plantations on pastoral } \\
\text { farms } \\
\text { - } 30 \% \text { more in scenic views like } \\
\text { trees, plantations on pastoral } \\
\text { farms }\end{array}$ & $\begin{array}{l}\text { Cultural services } \\
\text { Aesthetic value of } \\
\text { the agricultural } \\
\text { landscape } \\
\text { Cultural ES. Non- } \\
\text { extractive direct use } \\
\text { value (recreation) }\end{array}$ \\
\hline $\begin{array}{l}\text { Water quality/nitrate } \\
\text { leaching }\end{array}$ & $\begin{array}{l}\text { - Current ground water pollu- } \\
\text { tion due to nitrates } \\
\text { - } 10 \% \text { of the reduction of } \\
\text { ground water pollution } \\
\text { - } 20 \% \text { of the reduction of } \\
\text { ground water pollution }\end{array}$ & $\begin{array}{l}\text { - Current ground water pollu- } \\
\text { tion due to nitrates and urea } \\
\text { - } 10 \% \text { of the reduction maxi- } \\
\text { mum amount of fertilizer per- } \\
\text { mitted (included manure) } \\
\text { - } 20 \% \text { of the reduction maxi- } \\
\text { mum amount of fertilizer } \\
\text { permitted (included manure) } \\
30 \% \text { of the reduction maximum } \\
\text { amount of fertilizer permitted } \\
\text { (included manure) }\end{array}$ & $\begin{array}{c}\text { Regulating services } \\
\text { The quality of drink- } \\
\text { ing water } \\
\text { Indirect (regulating) } \\
\text { Direct } \\
\text { (provisioning) } \\
\text { Direct, indirect and } \\
\text { non-consumptive } \\
\text { benefits (cultural) }\end{array}$ \\
\hline Soil erosion & $\begin{array}{l}\text { - No changes } \\
\text { - } 10 \% \text { increasing perennial } \\
\text { grasslands area } \\
\text { - } 20 \% \text { increasing perennial } \\
\text { grasslands area } \\
\text { - } 30 \% \text { increasing perennial } \\
\text { grasslands area }\end{array}$ & $\begin{array}{c}\text { - No changes } \\
\text { - } 10 \% \text { increasing perennial } \\
\text { grasslands } \\
\text { - } 20 \% \text { increasing perennial } \\
\text { grasslands } \\
\text { - } 30 \% \text { increasing perennial } \\
\text { grasslands }\end{array}$ & $\begin{array}{l}\text { Indirect (regulating) } \\
\text { Direct and non-con- } \\
\text { sumptive } \\
\text { benefits (cultural) } \\
\text { Agrobiodiversity }\end{array}$ \\
\hline
\end{tabular}


Table. (continued)

\begin{tabular}{|c|c|c|c|}
\hline $\begin{array}{c}\text { Attributes } \\
\text { (functions } \\
\text { of agriculture) }\end{array}$ & Levels for crop production & $\begin{array}{l}\text { Levels for livestock } \\
\text { production }\end{array}$ & $\begin{array}{c}\text { Types of ecosystem } \\
\text { services }\end{array}$ \\
\hline $\begin{array}{l}\text { Diversity of flora } \\
\text { and fauna species } \\
\text { (wild life) - for crop } \\
\text { production } \\
\text { Agrobiodiversity } \\
\text { (species) - for live- } \\
\text { stock production } \\
\end{array}$ & $\begin{array}{l}\text { - No changes } \\
\text { - Enhancing of flora and fauna } \\
\text { diversity by reducing the ac- } \\
\text { tual level of pesticides of } 10 \% \\
\text { - Enhancing of flora and fauna } \\
\text { diversity by reducing the ac- } \\
\text { tual level of pesticides of } 20 \%\end{array}$ & $\begin{array}{l}\text { - Using only } 1 \text { race in each farm } \\
\text { for type of output } \\
\text { - Using at least } 2 \text { races in each } \\
\text { farm for type of output } \\
\text { - Using at least } 3 \text { races in each } \\
\text { farm for type of output }\end{array}$ & Supporting services \\
\hline Climate change & $\begin{array}{c}\text { • No changes } \\
\text { • } 10 \% \text { increasing dry pulses } \\
\text { area } \\
\text { • } 20 \% \text { increasing dry pulses } \\
\text { area } \\
\text { • } 30 \% \text { increasing dry pulses } \\
\text { area } \\
\end{array}$ & $\begin{array}{l}\cdot \text { No change } \\
\text { - Reducing } 10 \% \text { of the total } \\
\text { amount of polygrastic herd } \\
\text { - Reducing } 20 \% \text { of the total } \\
\text { amount of polygrastic herd }\end{array}$ & Supporting services \\
\hline $\begin{array}{l}\text { Personal contribu- } \\
\text { tion (EUR per year } \\
\text { for the next } 5 \text { years) }\end{array}$ & $0,6,12,24,48 \mathrm{EUR} /$ year & & \\
\hline
\end{tabular}

It was identified that during the preparation of the attributes and their levels different focus groups (Jianjun et al., 2013; Goibov et al., 2012; Grammatikopoulou et al., 2012; Hasund et al., 2011; Arriaza et al., 2008; et al.), pilot surveys (Jianjun et al., 2013; Hasund et al., 2011; Baskaran et al., 2009; Takastuka et al., 2006), personal interviews (Borresh et al., 2009) and experts' consultations (Dominguez, Solino, 2011; Colombo et al., 2005) are invoked.

Further steps of the research are preparation of the experimental design of the attributes, construction of the entire questionnaire, the applicability and feasibility of which for the Lithuanian case study will be verified by pilot survey(s). Following the construction of an appropriate framework, during the main survey, the data of the Lithuanian citizens' willingness to pay will be collected. It is expected to reveal their opinion and values in relation to different non-market outputs of farming systems. Then, NL econometric modelling will be applied and WTP will be elicited. It will be calculated as the ratio of cost and the relevant attribute (for example, landscape) and will express the value of different non-market agricultural outputs for Lithuanian residents. Since the research employs the hypothetical market scenarios, the values of residents WTP for different non-market outputs of farm- ing systems could be slightly underestimated or overestimated.

\section{CONCLUSIONS}

Agriculture not only supplies society with food and fibre, but also produces positive and negative externalities, which are not accounted for in the market economy, despite having a considerable impact on environment and the entire society. Conventional or intensive farming supports the society mostly with the market goods, and usually is a producer of negative externalities, while organic farming is perceived as having beneficial impacts on the environment compared to conventional farming. Agriculture plays a very important role for the Lithuanian case study, as more than $80 \%$ of the territory is occupied by rural areas. The major share of agricultural output is comprised of crop production, primarily production of cereals, followed by dairy.

The market output and gross value added from agriculture have been already evaluated, and the data are fully available in databases. The stated preference methods, i.e. CE and CV, are widely applied to evaluation of non-market outputs in agriculture. The CE method was selected for the evaluation of non-market outputs in the Lithuanian agriculture. For the analysis, 
conventional and organic farming were selected, considering two main agricultural activities: crop cereals and livestock production, considering their different outputs. For the estimation of the value of non-market output of selected farming systems, the NL was selected as an appropriate type, consisting of a nest with two possible alternatives of farming (conventional and organic), which could be managed in crop or livestock production. The methodology developed will be used for integrated evaluation of farming system outputs adapted to the Lithuanian case study.

\section{ACKNOWLEDGEMENTS}

This research was supported by the 2014-2020 Operational Programme for the European Union Funds Investments in Lithuania: Promotion of Post-Doctoral Fellowships (Contract No. 09.3.3-LMT-K-712-02-0103 DOTSUT-144).

Received 10 October 2018 Accepted 12 December 2018

\section{REFERENCES}

1. Abler D. 2004. Multifunctionality, agricultural policy and environmental policy. Agricultural and Resource Economics Review. Vol. 33(1). P. 8-17.

2. Adamowicz W., Boxall P., Williams M., Louviere J. 1998. Stated preference approaches for measuring passive use values: choice experiments and contingent valuation. American Journal of Agricultural Economics. Vol. 80(1). P. 64-75.

3. Aldanondo-Ochoa A. M., Almansa-Sáez C. 2009. The private provision of public environment: consumer preferences for organic production systems. Land Use Policy. Vol. 26. P. 669-682.

4. Allen K. E., Moore R. 2016. Moving beyond the exchange value in the nonmarket valuation of ecosystem services. Ecosystem Services. Vol. 18. P. 78-86.

5. Aravena C., Martinsson P., Scarpa R. 2014. Does money talk? The effect of a monetary attribute on the marginal values in a choice experiment. Energy Economics. Vol. 44. P. 483-491.

6. Arriaza M., Gomez-Limon J. A., Kallas Z., Nekhay O. 2008. Demand for non-commodity outputs from mountain olive groves? Agricultural Economics Review. Vol. 9(1). P. 5-23.

7. Baskaran R., Cullen R., Colombo S. 2009a. Estimating values of environmental impacts of dairy farming in New Zealand. New Zealand Journal of Agricultural Research. Vol. 52(4). P. 377-389.

8. Baskaran R., Cullen R., Takatsuka Y. 2009b. Estimating the value of agricultural ecosystem ser- vices: a case study of New Zealand pastoral farming. Australasian Journal of Environmental Management. Vol. 16(2). P. 103-112.

9. Bateman I. J., Carson R. T., Day B., Hanemann M., Hanley N., Hett T., Jones-Lee M., Loomes G., Mourato S., Özdemiroglu E., Pearce D. W., Sugden R., Swanson J. 2002. Economic Valuation with Stated Preference Techniques: A Manual. Cheltenham: Edward Elgar.

10. Bennett J., Blamey R. 2001. The Choice Modelling Approach to Environmental Valuation. Cheltenham, UK; Northampton, MA, USA: Edward Elgar.

11. Bernués A., Rodríguez-Ortega T., Alfnes F., Clemetsen M., Eik L. O. 2015. Quantifying the multifunctionality of fjord and mountain agriculture by means of sociocultural and economic valuation of ecosystem services. Land Use Policy. Vol. 48. P. $170-178$.

12. Boody G. 2008. Multifunctional agriculture: more than bread alone. Bioscience. Vol. 58(8). P. 762-763.

13. Borresch R., Maas S., Kim Schmitz P., Schmitz M. 2009. Modelling the Value of a Multifunctional Landscape - A Discrete Choice Experiment. Contributed Paper prepared for presentation at the International Association of Agricultural Economists Conference, Beijing, China, 16-22 August 2009.

14. Chaikaew P., Hodges A. W., Grunwald S. 2017. Estimating the value of ecosystem services in a mixed-use watershed: a choice experiment approach. Ecosystem Services. Vol. 23. P. 228-237.

15. De Cicco A. 2016. Dry Pulses in EU Agriculture - Statistics on Cultivation, Production and Economic Value. Available at: https://ec.europa.eu/ eurostat/statistics-explained/index.php/Dry_ pulses_in_EU_agriculture_-_statistics_on_ cultivation,_production_and_economic_value

16. Doherty E., Murphy G., Hynes S., Buckley C. 2014. Valuing ecosystem services across water bodies: results from a discrete choice experiment. Ecosystem Services. Vol. 7. P. 89-97.

17. Domínguez-Torreiro M., Soliño M. 2011. Provided and perceived status quo in choice experiments: Implications for valuing the outputs of multifunctional rural areas. Ecological Economics. Vol. 70(12). P. 2523-253. DOI: 10.1016/j.ecolecon.2011.08.021.

18. Enriquez-Acevedoa T., Boterob C. M., CanteroRodeloa R., Pertuza A., Suarez A. 2018. Willingness to pay for Beach Ecosystem Services: The case study of three Colombian beaches. Ocean \& Coastal Management. Vol. 161. No. 1. P. 96-104.

19. European Commission. 2017. Agriculture and Rural Development. CAP and Rural Development. Available at: https://ec.europa.eu/agriculture/ organic/eu-funding/cap-andrural-development_en

20. Europos Komisijos 2013 m. spalio 4 d. ataskaita dèl Nitratu direktyvos igyvendinimo 2008-2011 m. ES27 valstybèse narèse. 
21. Goibov M., Schmitz P. M., Bauer S., Ahmed M. N. 2012. Application of a choice experiment to estimate farmers preferences for different land use options in Northern Tajikistan. Journal of Sustainable Development. Vol. 5(5). P. 2-16.

22. Grammatikopoulou I., Pouta E., Salmiovirta M., Soini K. 2012. Heterogeneous preferences for agricultural landscape improvements in Southern Finland. Landscape and Urban Planning. Vol. 107(2). P. 181-191.

23. Hasund K. P., Kataria M., Lagerkvist C. J. 2011. Valuing public goods of the agricultural landscape: a choice experiment using reference points to capture observable heterogeneity. Journal of Environmental Planning and Management. Vol. 54(1). P. 31-53.

24. Hensher D. A., Rose J. M., Greene W. H. 2005. Applied choice analysis: A primer. United Kingdom: Cambridge University Press.

25. Hensher D. A., Greene W. H. 2002. Specification and estimation of the nested logit model: alternative normalizations. Transportation Research Part B. Vol. 36. P. 1-17.

26. Houessionon P, Fonta W. M., Bossa A. Y., Sanfo S., Thiombiano N., Zahonogo P., Thomas B. Yameogo T. B., Balana B. 2017. Economic valuation of ecosystem services from small-scale agricultural management interventions in Burkina Faso: A discrete choice experiment approach. Sustainability. Vol. 9. P. 1672. DOI: 10.3390/su9091672.

27. Jespersen L. M., Baggesen D. L., Fog E., Halsnæs K., Hermansen J. E., Andreasen L., Strandberg B., Sørensen J. T., Halberg N. 2017. Contribution of organic farming to public goods in Denmark. Organic Agriculture. Vol. 7. P. 243-266.

28. Jianjun J., Rui H., Wenyu W., Haozhou G. 2018. Valuing cultivated land protection: A contingent valuation and choice experiment study in China. Land Use Policy. Vol. 74. P. 214-219.

29. Jianjun J., Chong J., Thuy T. D., Lun L. 2013. Public preferences for cultivated land protection in Wenling city, China: a choice experiment study. Land Use Policy. Vol. 30(1). P. 337-343.

30. Junge X., Schüpbach B., Walter T., Schmid B., Lindemann-Matthies P. 2015. Aesthetic quality of agricultural landscape elements in different seasonal stages in Switzerland. Landscape and Urban Planning. Vol. 133. P. 67-77.

31. Khanal U., Wilson C., Managi S., Lee B., Hoang V., Gifford R. 2017. Psychological influence on survey incentives: valuing climate change adaptation benefits in agriculture. Environmental Economics and Policy Studies. August 2017. P. 1-21. DOI: 10.1007/ s10018-017-0195-4.

32. Kubiszewski I., Costanza R., Anderson S., Sutton P. 2017. The future value of ecosystem services: global scenarios and national implications. Ecosystem Services. Vol. 26. P. 289-301.
33. Lancaster K. J. 1966. A new approach to consumer theory. Journal of Political Economy. Vol. 74. P. 132157.

34. Lankoski J. 2003. The Environmental Dimension of Multifunctionality: Economic Analysis and Implications for Policy Design. PhD Thesis. University of Helsinki.

35. Lithuanian Institute of Agrarian Economics. 2018. Agriculture and Food Sector in Lithuania 2017. Vilnius.

36. Madureira L., Lima Santos J., Ferreira A., Guimarães H. 2013. Feasibility Study on the Valuation of Public Goods and Externalities in EU Agriculture. European Commission.

37. Mann S., Wustemann H. 2008. Multifunctionality and a new focus on externalities. The Journal of Socio-Economics. Vol. 37(1). P. 293-307.

38. Marre J., Brander L., Thebaud O., Boncoeur J., Pascoe S., Conglan L., Pascal N. 2015. Non-market use and non-use value for preserving ecosystem services over time: a choice experiment application to coral reef ecosystems in New Caledona. Ocean \& Coastal Management. Vol. 105. P. 1-14.

39. McFadden D. 1974. Conditional logit analysis of qualitative choice behaviour. In: Zarembka P. (ed.). Frontiers in Econometrics. New York: Academic Press. P. 105-142.

40. Ministry of Agriculture of the Republic of Lithuania. 2014. Lithuania - Rural Development Programme 2014-2020. Lithuania.

41. Nacionalinè žemès tarnyba prie Lietuvos žemès ūkio ministerijos. 2017. Lietuvos Respublikos žemès fondas, $2017 \mathrm{~m}$. sausio $1 \mathrm{~d}$. Vilnius (In Lithuanian).

42. Neuteleers S., Engelen B. 2014. Talking money: how market-based valuation can undermine environmental protection. Ecological Economics. Vol. 117. P. 253-260.

43. Novikova A., Startiene G. 2018. Analysis of Farming System Outputs and Methods of Their Evaluation. Research for Rural Development 2018 (In press).

44. Novikova A., Rocchi L., Vitunskiene V. 2017. Assessing the benefit of the agroecosystem services: Lithuanian preferences using a latent class approach. Land Use Policy. Vol. 68. P. 277-286.

45. Olschewski R., Bebi P., Teich M., Wissen Hayek U., Grêt-Regamey A. 2012. Avalanche protection by forests - A choice experiment in the Swiss Alps. Forest Policy and Economics. Vol. 17. P. 19-24.

46. Pretty J., Brett C., Gee D., Hine R., Mason C., Morison J., Rayment M., van der Bijl G., Dobbs T. 2001. Policy challenges and priorities for internalizing the externalities of modern agriculture. Journal of Environmental Planning and Management. Vol. 44(2). P. 263-283.

47. Rakotonarivo O. S., Jacobsen J. B., Larsen H. O., Jones J. P. G., Nielsen M. R., Ramamonjisoa B. S., Mandimbiniaina R. H., Hockley N. 2017. Qualitative 
and quantitative evidence on the true local welfare costs of forest conservation in Madagascar: Are discrete choice experiments a valid ex ante tool? World Development. Vol. 94. P. 478-491.

48. Scottish Government. 2018. Ecological Focus Areas. Available at: https://www.ruralpayments.org/publicsite/futures/topics/all-schemes/basic-paymentscheme/basic-payment-scheme-full-guidance/ greening-guidance-2018/efa-ecological-focus-areas/

49. Soto J. R., Escobedo F. J., Khachatryan H., Adams D. C. 2018. Consumer demand for urban forest ecosystem services and disservices: Examining trade-offs using choice experiments and best-worst scaling. Ecosystem Services. Vol. 29(Part A). P. 3139.

50. Szabó Z. 2010. Evaluation of Environmental Impacts of Crop Production, with Particular Focus on Biodiversity: External Impacts of an Intensive Farm and an Ecological Farm. PhD Dissertation. Corvinus University of Budapest.

51. Tait P., Cullen R. 2006. Some External Costs of Dairy Farming in Canterbury. Paper presented at the 50th Australian Agricultural and Resource Economics Society Annual Conference. Sydney, Australia, 8-10 February.

52. Takatsuka Y., Cullen R., Wilson M., Wratten S. 2006. Values of Ecosystem Services on Arable Land and the Role of Organic Farming. Paper prepared for the 3rd World Congress of Environmental and Resource Economists. Kyoto, Japan, 3-7 July 2006.

53. Tegtmeier E. M., Duffy M. D. 2004. External costs of agricultural production in the United States. International Journal of Agricultural Sustainability. Vol. 2(1). P. 1-20.

54. Teizzi S. 1999. External effects of agricultural production in Italy and environmental accounting. Environmental and Resource Economics. Vol. 13(4). P. 459-472.

55. Thurstone L. 1927. A law of comparative judgement. Psychological Review. Vol. 34(4). P. 273-286.

56. Valstybine maisto ir veterinarijos tarnyba. 2018. Gyvūnu gerovè. Prieiga per internetą: http://vmvt.lt/ node/565

57. Vivithkeyoonvong S., Jourdain D. 2017. Willingness to pay for ecosystem services provided by irrigated agriculture in Northeast Thailand. International Journal of Biodiversity Science, Ecosystems Services and Management. Vol. 13. P. 14-26.

58. Wagner S., Angenendt E., Beletskaya O., Zeddies J. 2017. Assessing ammonia emission abatement measures in agriculture: Farmers' costs and society's benefits - A case study for Lower Saxony, Germany. Agricultural Systems. Vol. 157. P. 70-80. DOI: 10.1016/j.agsy.2017.06.008.

59. Williams G., Rolfe J. 2017. Willingness to pay for emissions reduction: Application of choice modeling under uncertainty and different management options. Energy Economics. Vol. 62. P. 302-311.
60. Williams H. C. W. L. 1977. On the formation of travel demand models and economic evaluation measures of user benefit. Environment and Planning, Part A. Vol. 9. P. 285-344.

61. Zhukova Y., Petrov P., Demikhov Y., Mason A., Korostynska O. 2017. Milk urea content and $\delta 13 \mathrm{C}$ as potential tool for differentiation of milk from organic and conventional Low- and High-Input Farming systems. Turkish Journal of AgricultureFood Science and Technology. Vol. 5(9). P. 10441050. DOI: 10.24925/turjaf.v5i9.1044-1050.1286.

\section{Anastasija Novikova, Lucia Rocchi, Gražina Startienè ÜKININKAVIMO SISTEMŲ PRODUKCIJOS IVERTINIMAS LIETUVOJE: METODOLOGINIS PAGRINDAS}

Santrauka

Žemès ùkis kuria prekines ir neprekines gèrybes, kurių pasiūla priklauso nuo gamybos specifikos. Lietuvos atveju, žemès ūkio kaip ekonominès veiklos vaidmuo yra labai svarbus ne tik dèl kuriamos produkcijos, bet ir ịvertinant tai, kad žemès ūkio paskirties žemè užima daugiau nei pusę Lietuvos teritorijos. Tačiau agroekosistemose kuriami teigiami ir neigiami išoriniai efektai nèra apskaitomi rinkoje. Žemès ūkio viešųjų gèrybių vertei nustatyti gali būti naudojami specifiniai metodai, pavyzdžiui, pareikšto prioriteto metodai. Užsienio mokslininkai atlieka išsamius tyrimus vertindami neprekinę žemès ūkio produkciją, dažniausiai jie koncentruojasi į žemès ūkio veiklos naudos arba žalos nustatymą. Pasigendama kompleksinio ūkininkavimo sistemų rezultatų vertinimo, atsižvelgiant $\mathfrak{i}$ ūkininkavimo specifiką ir intensyvumą. Pagrindinis šio straipsnio tikslas - pristatyti ūkininkavimo sistemu produkcijos kompleksinio vertinimo metodologiją Lietuvoje, pagrindini dèmesį skiriant viešųų gèrybių vertinimui. Lietuvos atvejo analizei pasirinktos tradicinio ir ekologinio ūkininkavimo sistemos. Tyrimas aprèpia dvi ūkininkavimo sistemas, t. y. augalininkystę (įskaitant grūdinius ir pramoninius augalus) ir gyvulininkystę (ịskaitant pieno gamybą ir galvijininkystę). Straipsnyje pagrindžiamas pasirinkimo eksperimentų metodo tinkamumas ịvairių Lietuvos ūkininkavimo sistemų teikiamų viešųų gèrybių vertei nustatyti. Žemès ūkio viešujų gerybių vertės ekonometriniam modeliavimui buvo pasirinktas „Nested logit“ metodas. Pagal sukurtą ir patikrintą metodiką pagrindiniame tyrime bus nustatytas polinkis mokèti už įvairių ūkininkavimo sistemų teikiamas viešąsias gèrybes.

Raktažodžiai: ūkininkavimo sistema, rinkos gèrybès, viešosios gèrybès, tradicinis ūkininkavimas, ekstensyvus ūkininkavimas, pasirinkimo eksperimentai, Lietuva 